\title{
Haematological and antioxidant enzyme response to Lead toxicity in male Wistar rats
}

\author{
B.S. Okediran ${ }^{1}$, K.T. Biobaku ${ }^{2}$, F.H. Olaifa ${ }^{1}$ and A.J. Atata $^{3}$ \\ ${ }^{1}$ Department of Veterinary Physiology and Biochemistry, Faculty of Veterinary Medicine, University of Ilorin, \\ Ilorin, Nigeria. \\ ${ }^{2}$ Department of Veterinary Pharmacology and Toxicology, Faculty of Veterinary Medicine, University of Ilorin, \\ Ilorin, Nigeria. \\ ${ }^{3}$ Department of Veterinary Pathology, Faculty of Veterinary Medicine, University of Ilorin, Ilorin, Nigeria
}

Received: 24/11/2016; Accepted: 16/02/2017

\begin{abstract}
The study evaluated the haematological and some antioxidant enzymes response to lead toxicity in male Wistar rats. Twenty male Wistar rats were divided into four groups viz., A, B, C and D. Group A served as the control while groups B, C and D were treated with 200,300 and 400 ppm of lead $(\mathrm{Pb})$ as lead acetate, respectively. Doses were orally administered in divided doses by intubation to ensure that each rat had the specified doses, after which they have access to water and feed. At the end of two weeks of treatment, blood samples were collected via the median canthus into heparinised tubes for blood lead determination and haematological analysis after which the remaining blood was centrifuged to obtain the plasma for determination of malonydialdehyde, catalase, superoxide dismutase and peroxidase levels. There was a significant increase in blood lead concentrations ranging from $2.15 \pm 0.10 \mu \mathrm{g} / \mathrm{dl}$ to $9.21 \pm 0.05 \mu \mathrm{g} / \mathrm{dl}$ which was dose dependent while decreases in packed cell volume and the red blood cell counts ranging from $32-53 \%$ and 15 $52 \%$,respectively. At the highest dose of $400 \mathrm{ppm}$ of lead there was significant decrease in the neutrophils and lymphocytes. There was significant $(\mathrm{P}<0.05)$ dose dependent increases in malondialdehyde while the activities of catalase, peroxidase and superoxide dismutase were significantly $(\mathrm{P}<0.05)$ reduced. In conclusion, lead disrupts the haematological system leading to generation of free radicals that overwhelm the antioxidant enzymes thus leading to oxidative stress.
\end{abstract}

Keywords: Haematological, malonydialdehyde oxidative stress, free radicals.

\section{INTRODUCTION}

Lead poisoning is one of the intoxications most frequently found in the environment, mainly due to anthropogenic activities. Lead is a heavy metal with an evidence of toxicity with widely recognized ubiquitous, long-lived and pervasive environmental and industrial toxicant throughout the world (Ademuyiwa et al., 2007; Spivey, 1978).

Lead has been found to produce a wide range of toxic-biochemical effects involving several organs, systems and biochemical activities (Ademuyiwa et al., 2002; Sakai, 2000). Neurobehavioral, haematologic, nephrotoxic and reproductive effects of lead have been observed in humans and other animals (Goyer, 1991; Needleman et al., 1990).

The alteration of the haem synthesis is an early effect associated with increased lead concentration in soft tissues. Inhibition of delta aminolevulinic acid dehydratase (ALAD) and elevation of protoporphyrin in erythrocytes are the earliest effects, followed by increased delta aminolevulinic acid (ALA) and coproporphyrin excretion in urine (Makino et al., 2000; Sakai, 2000).

Lipid peroxidation, as evidenced by increased malondialdehyde content as well as alterations in membrane integrity and fatty acid composition, have been observed in red blood cells of animals and humans exposed to lead (Gurer et al., 1999; Osterode and Ulberth, 2000). Lead produces oxidative damage in the liver and kidney as evidenced by enhancing lipid peroxidation (Shafiq-ur-Rehman, 1984; Somashekaraiah et al., 1992). Liver plays a major role in lead metabolism and it is therefore in special risk due to its oxidative action, given the unquestionable evidences that lead-induced lipid peroxidation of cellular membranes play a crucial role in the mechanism of hepatotocellular damage (Sivaprasad et al., 2004). 
In vivo and in vitro studies suggest that lipid metabolism is altered both in acute and chronic exposure to lead (Ademuyiwa et al., 2009). Reports have indicated that antioxidant enzymes play a crucial role in the protection of cells against oxidative stress caused by lead toxicity (Sivaprasad et al., 2004; Ozturk et al., 2001). For these reasons, we assayed for antioxidant enzymes viz., catalase, superoxide dismutase, peroxidase in addition to product of lipid peroxidation, malondialdehyde in male Wistar rats exposed to graded concentrations of lead acetate to elucidate the responses of these scavenging enzymes to the effects of lead toxicity.

\section{MATERIALS AND METHODS}

\section{Experimental animals}

A total of twenty male Wistar rats were used for this study. The average weight of the rats was $152 \pm 3.5 \mathrm{~g}$. They were provided with laboratory animal feed (Fat/oil 6\%, Crude fibre 5\%, Calcium 1\%, Available phosphorus 0.4\%, Lysine $0.85 \%$, Methionine $0.35 \%$, Salt $0.3 \%$, Crude protein 18\%, Metabolisable Energy 2900 Kcal.kg ${ }^{-1}$, (TOPFEEDS ${ }^{\circledR}$, Lagos, Nigeria) and water ad libitum. Experimental animals were acclimatized to their housing environment one month before the start of the experiment.

\section{Animal ethics}

All experimental protocols carried out on the animals were in accordance with the internationally accepted principles for laboratory animal use and were approved by the Ethics Committee on Laboratory Animal Use of the College of Veterinary Medicine, Federal University of Agriculture, Abeokuta, Nigeria.

\section{Administration of lead acetate}

The animals were randomly divided into four groups consisting of five animals each. They were dosed with lead acetate orally for a period of two weeks. The treatments were as follows:

Group A: served as the control and was given distilled water.

Group B: was given 200 ppm (parts per million) of lead as lead acetate.

Group C: was given 300 ppm of lead as lead acetate.
Group D: was given 400 ppm of lead as lead acetate.

Lead acetate, $\left(\mathrm{CH}_{3} . \mathrm{COO}\right)_{2} \mathrm{~Pb} .3 \mathrm{H}_{2} \mathrm{O}$, Assay (ex $\mathrm{Pb}$ ) 99-103\%, maximum limits of Impurities, Chloride $\left(\mathrm{Cl}^{-}\right)$0.005\%, Copper $\left.(\mathrm{Cu}) 0.002 \%\right)$ (Cartivalues, England).

\section{Collection of blood samples}

At the end of two weeks treatment, blood samples were collected via the occular median canthus using heparinized capillary tubes into heparinized tubes. Packed cell volume, red blood cell and white blood cell count were determined as described by Frankel and Reitman, (1963), while plasma was separated from whole blood samples as described by Schalm et al., (1975).

\section{Plasma preparation}

The blood samples were centrifuged at $4000 \mathrm{rpm}$ for 10 minutes to separate the plasma from the red blood cells (erythrocytes). The plasma was then removed and stored in Eppendorf tubes for further analyses.

\section{Blood lead determination}

Lead was analyzed in whole blood using Atomic Absorption Spectrometry (Buck Scientific AAS model 200, Connecticut, USA).

\section{Estimation of lipid peroxidation}

Product of lipid peroxidation, malondialdehyde (MDA) was estimated according to the method described by Buege and Aust (1978).

\section{Enzymatic assay of antioxidant enzymes}

Plasma catalase was assayed as described by Sinha (1972) while superoxide dismutase was assayed as described by Zou et al. (1986). Peroxidase was assayed as described by Sharon (1966).

\section{Statistical analysis}

Results were expressed as mean \pm SEM. Analysis of the data was done using one-way analysis of variance followed by the Duncan multiple range post hoc test. $\mathrm{P}$ value $<0.05$ were considered significant. All analyses were done using Statistical Package for Social Sciences version 16. 


\section{RESULTS}

Table 1 shows the blood lead concentrations, packed cell volume, red blood cells and white blood cells counts of male Wistar rats treated with $\mathrm{Pb}$ for a period of two weeks. There were significant increases $(\mathrm{P}<0.05)$ in blood $\mathrm{Pb}$ concentrations of treated rats compared to the control group and was dose dependent. Highest blood lead concentration was recorded at 400 ppm treatment which was about 4.3 times of that of the control group. The packed cell volume and red blood cell count revealed a dose dependent significant decrease $(\mathrm{P}<0.05)$. The decrease in packed cell volume and red blood cell count ranges from $32-53 \%$ and $15-52 \%$ compared to the control group respectively. Though there was decrease in the white blood cell count, it was however only at $400 \mathrm{ppm}$ treatment that a significant decrease $(\mathrm{P}<0.05)$ of about $35 \%$ was observed.

Table 2 shows the neutrophil, basophil, eosinophil, lymphocyte and monocyte counts of male Wistar rats treated with $\mathrm{Pb}$ for a period of two weeks. There was no significant change in eosinophil, basophil and monocyte counts of treated rats compared to the control group. However, at higher doses of $300 \mathrm{ppm}$ and 400 ppm of $\mathrm{Pb}$ a significant decrease $(\mathrm{P}<0.05)$ was observed in the neutrophil counts while significant increase $(\mathrm{P}<0.05)$ was observed in the lymphocyte counts.

Table 3 shows the mean concentration of malondialdehyde and activities of catalase, peroxidase and superoxide dismutase of male Wistar rats treated with $\mathrm{Pb}$ for a period of two weeks. There was significant increase $(\mathrm{P}<0.05)$ in the concentration of plasma malondialdehyde which was dose dependent, while there were significant decreases $(\mathrm{P}<0.05)$ in the activities of catalase, peroxidase and superoxide dismutase in rats treated with lead. These decreases were dose dependent as well.

Table 1: The blood lead $(\mathrm{Pb})$ concentrations, packed cell volume (PCV), red blood cell counts (RBC) and white blood cell counts (WBC) of male Wistar rats treated with lead for a period of two weeks (mean \pm SEM).

\begin{tabular}{lllll}
\hline Treatments & $\mathbf{P b}(\boldsymbol{\mu g} / \mathbf{d l})$ & PCV $(\%)$ & RBC Count $^{\left(10^{12} / \mathbf{L}\right)}$ & WBC Count $(\mathbf{1 0} / \mathbf{L})$ \\
\hline Control & $2.15 \pm 0.10^{\mathrm{a}}$ & $43.00 \pm 3.22^{\mathrm{b}}$ & $5.94 \pm 0.23^{\mathrm{c}}$ & $10.30 \pm 0.26^{\mathrm{b}}$ \\
$200 \mathrm{ppm}$ & $4.01 \pm 0.21^{\mathrm{b}}$ & $29.33 \pm 2.33^{\mathrm{a}}$ & $5.05 \pm 0.79^{\mathrm{c}}$ & $9.32 \pm 0.29^{\mathrm{b}}$ \\
$300 \mathrm{ppm}$ & $7.11 \pm 0.27^{\mathrm{c}}$ & $26.33 \pm 1.84^{\mathrm{a}}$ & $4.26 \pm 0.13^{\mathrm{b}}$ & $8.88 \pm 0.55^{\mathrm{b}}$ \\
$400 \mathrm{ppm}$ & $9.21 \pm 0.05^{\mathrm{c}}$ & $20.00 \pm 2.71^{\mathrm{a}}$ & $2.84 \pm 0.50^{\mathrm{a}}$ & $6.65 \pm 0.44^{\mathrm{a}}$ \\
\hline
\end{tabular}

Values within the same column with different superscripts are significantly different at $\mathrm{p}<0.05$

Table 2: The mean differential leucocyte counts of male Wistar rats treated with lead for a period of two weeks (mean \pm SEM).

\begin{tabular}{llllll}
\hline Treatments & Neutrophil (\%) & Eosinophil (\%) & Basophil (\%) & Monocyte (\%) & $\begin{array}{l}\text { Lymphocyte } \\
(\%)\end{array}$ \\
\hline Control & $56.67 \pm 3.18^{\mathrm{b}}$ & $1.33 \pm 0.33^{\mathrm{a}}$ & $1.00 \pm 0.58^{\mathrm{a}}$ & $1.00 \pm 0.58^{\mathrm{a}}$ & $40.00 \pm 3.06^{\mathrm{a}}$ \\
$200 \mathrm{ppm}$ & $54.00 \pm 3.06^{\mathrm{b}}$ & $1.00 \pm 0.58^{\mathrm{a}}$ & $0.67 \pm 0.33^{\mathrm{a}}$ & $0.67 \pm 0.23^{\mathrm{a}}$ & $38.66 \pm 4.38^{\mathrm{a}}$ \\
$300 \mathrm{ppm}$ & $44.50 \pm 4.18^{\mathrm{a}}$ & $1.00 \pm 0.58^{\mathrm{a}}$ & $0.67 \pm 0.33^{\mathrm{a}}$ & $0.33 \pm 0.01^{\mathrm{a}}$ & $24.50 \pm 0.88^{\mathrm{b}}$ \\
$400 \mathrm{ppm}$ & $40.00 \pm 1.16^{\mathrm{a}}$ & $0.67 \pm 0.21^{\mathrm{a}}$ & $0.67 \pm 0.33^{\mathrm{a}}$ & $0.33 \pm 0.01^{\mathrm{a}}$ & $22.33 \pm 1.16^{\mathrm{b}}$ \\
\hline
\end{tabular}

Values within the same column with different superscripts are significantly different at $\mathrm{p}<0.05$. 
Table 3: The mean concentration of malondialdehyde and activities of antioxidant enzymes of male Wistar rats treated with lead for a period of two weeks (mean \pm SEM).

\begin{tabular}{lllll}
\hline Treatments & $\begin{array}{l}\text { Malondialdehyde } \\
(\mathbf{n m o l} / \mathbf{m l})\end{array}$ & $\begin{array}{l}\text { Catalase } \\
(\boldsymbol{\mu m o l} / \mathbf{m i n})\end{array}$ & $\begin{array}{l}\text { Peroxidase } \\
(\text { units/ml enzyme) }\end{array}$ & $\begin{array}{l}\text { Superoxide } \\
\text { dismutase (units) }\end{array}$ \\
\hline Control & $13.20 \pm 2.87^{\mathrm{a}}$ & $0.83 \pm 0.16^{\mathrm{b}}$ & $0.52 \pm 0.07^{\mathrm{b}}$ & $33.12 \pm 7.61^{\mathrm{a}}$ \\
$200 \mathrm{ppm}$ & $15.04 \pm 2.01^{\mathrm{b}}$ & $0.49 \pm 0.18^{\mathrm{a}}$ & $0.50 \pm 0.09^{\mathrm{b}}$ & $28.04 \pm 7.56^{\mathrm{b}}$ \\
$300 \mathrm{ppm}$ & $19.22 \pm 2.11^{\mathrm{c}}$ & $0.43 \pm 0.15^{\mathrm{a}}$ & $0.25 \pm 0.11^{\mathrm{a}}$ & $22.83 \pm 5.61^{\mathrm{b}}$ \\
$400 \mathrm{ppm}$ & $21.54 \pm 3.12^{\mathrm{c}}$ & $0.31 \pm 0.16^{\mathrm{a}}$ & $0.22 \pm 0.08^{\mathrm{a}}$ & $12.96 \pm 2.48^{\mathrm{b}}$ \\
\hline
\end{tabular}

Values within the same column with different superscripts are significantly different at $p<0.05$.

\section{DISCUSSION}

Lead is not known to serve any necessary biological function within the body and its presence in the body may lead to toxic effects. It has been recognized as a major heavy metal pollutant in some areas, because of its wide distribution in the environment. It is one of the most pervasive heavy metals contaminant with wide spread industrial and domestic applications. It is a poison to living organisms, with negative effects on general health, reproduction and behavior which could result in death (Finkel et al., 1983). Blood or blood constituents are the best indicators of internal exposure of an individual to lead. The result in table 1 shows an increase in the blood lead concentrations which was consistent with earlier findings (Okediran et al., 2010; Moussa and Bashandy, 2008) where they showed that absorbed lead following oral ingestion is carried via blood to soft tissues and 95\% of blood lead is transported on the erythrocyte as lead diphosphate. Accumulation of lead produces damaging effects in the haematological, haematic, renal and gastrointestinal systems (Correia et al., 2000). The toxicity depends on its chemical form, the route, frequency and duration of administration. The lower packed cell volume coupled with reduction in red blood cell count observed in this study revealed the presence of anaemia. Leadinduced anaemia could be due to the interference of lead with haem biosynthesis through inhibition of $\delta$-aminolevulinic acid dehydratase and ferochelatase activities and by also decreasing erythrocyte survival (Suleiman et al., 2010). The interference of lead with the development of haematopoietic progenitor and alteration of production of renal erythropoietin are increasingly linked with anaemia in lead poisoning (Osterode et al., 1999). Similarly, increased plasma malonldialdehyde (MDA) concentration indicating membrane lipoperoxidation which was recorded in the present study suggest an increased oxidative damage to the erythrocyte membranes, which has been associated with increased red blood cell fragility (Suleiman et al., 2010).

Analysis of total leucocyte and differential leucocyte counts revealed dose dependent leucopenia and lymphopenia in higher dose groups of $300 \mathrm{ppm}$ and $400 \mathrm{ppm}$. This might be due to direct toxic action of $\mathrm{Pb}$ on leucopoiesis in lymphoid organs. Decrease in total leucocyte count is directly related with either decreased production from germinal center of lymphoid organs or increased lysis due to presence of $\mathrm{Pb}$ in the body (Avadheshkumar, 1998). Repeated exposure to lead has been demonstrated to induce lymphopenic leucopenia (Hashem and ElSharkawy, 2009). The leucopenia observed in this study also shows the level of stress being experienced by the rats as a result of exposure to the $\mathrm{Pb}$ thus inducing oxidative damage to the leucocytes. Malondialdehyde is a well established biomarker of cellular injury and is used as an indicator of oxidative stress in cells and tissues (Kihc et al., 2003). Oxidative stress and enhanced lipid peroxidation have been associated with several models of liver and tissue injury (Panazzo et al., 1995)

Dose dependent increase in plasma malondialdehyde (MDA) concentration was observed in this study. This is an indication of increased lipid peroxidation in the lead treated groups compared to the control. The increased malondialdehyde was produced at a higher rate than what the antioxidant enzymes could cope with thus overwhelming the defense system. This 
increased lipoperoxidative changes compromises the structural integrity of the cellular membranes. Levels of MDA were significantly increased in lead treated groups, this could be due to decrease activity of the defense system protecting tissues from free radicals damage. The presence of unsaturated fatty acids in cell membrane makes the membrane susceptible to peroxidation. The peroxidation of cell membrane leads to the impairment in its semi-permeability and triggers the series of reactions that may result in cell death (Comporti, 1993; Gutterridge, 1993). Many heavy metals including lead are known to induce over production of reactive oxygen species (ROS) or free radicals and consequently enhance lipid peroxidation, decrease the saturated fatty acids and increase the unsaturated fatty acids content of membranes (Maleeka et al., 2001). Lead has been reported to enhance the production of ROS in a variety of cells resulting in oxidative stress (Xienna et al., 2000). ROS are the byproducts of many degenerative reactions in many tissues, which affect regular metabolism by damaging the cellular components (Foyer and Noctor, 2002). Extensive study on oxidative stress has demonstrated that exposure of cells to adverse environmental conditions can induce the over production of ROS, such as superoxide radicals, $\left(\mathrm{O}_{2}^{-}\right), \mathrm{H}_{2} \mathrm{O}_{2}$ and hydroxyl radicals $\left(\mathrm{OH}^{-}\right)$ in cells (Wise and Neylor, 1987). In addition, reactive oxygen species are highly reactive to membrane lipids, proteins and DNA. They are believed to be the major contributing factors to stress injuries and to cause rapid cellular damage (Aly and El-Beltagi, 2010; El-Beltagi et al., 2011). There are several intracellular defense mechanisms to prevent the potential oxidative damage. These defense systems are classified as enzymatic and non-enzymatic. The enzymatic defense systems include the antioxidant enzymes. These enzymes protect the cell membrane against peroxidation by converting the reactive compounds to less harmful or harmless metabolites. The determinations of MDA concentrations and antioxidant enzymes activities are the major criteria concerning the severity of possible peroxidation, which takes place in cell membrane (Aydemir et al., 2000; Gokhan et al., 2004; Ozturk-Ureket al., 2001). The decrease in activities of these antioxidant enzymes proved that lead indeed induced generation of reactive oxygen species/free radicals leading to increase production of MDA which was much higher than the level which could be compensated by the cellular defense systems, thus these compounds may not be converted to less harmful or ineffective metabolites at the sufficient levels. The increase in MDA which was dose dependent could be attributed to lead acetate ingestion causing alteration in redox status as indicated by a decrease in enzymatic antioxidant status which may be produced by damage in red blood cells (Seddik et al., 2010). Antioxidant enzymes were affected by higher doses of lead, heavy metals induced toxicity through the depletion of antioxidant enzymes resulting in enhanced production of reactive oxygen species such as peroxide ion, hydroxyl radicals and hydrogen peroxide, and these reactive oxygen species increased lipids peroxidation and cell membrane damage(El-Beltagi and Mohammed, 2010; Zhang et al., 2007).

These results further suggest or confirm earlier findings, the involvement of free radicals in the pathogenesis of lead poisoning. Lead is a protoplasmic poison which can cause damages to many organic bodies. There is little doubt that haematological parameters are seriously affected due to free radicals generated as a result of lead treatment thus reducing the activities of the antioxidant enzymes. Lead also caused disturbances in the body metabolism as well as oxidative-antioxidative balance in different tissues and plasma. These results suggest that the harmful effects observed in this study were produced by a dose dependent lead toxicant.

\section{REFERENCES}

Ademuyiwa O, Ugbaja RN, Rotimi SO, Abam E, Okediran BS, Dosumu OA \& Onunkwor BO (2007). Erythrocyte acetylcholinesterase activity as a surrogate indicator of lead-induced neurotoxicity in occupational lead exposure in Abeokuta, Nigeria.Environmental Toxicology and Pharmacology 24: 183-188.

Ademuyiwa O, Arowolo T, Ojo DA, Odukoya OO, Yusuf AA \& Akinhanmi TF (2002). Lead levels in blood and urine of some residents of Abeokuta, Nigeria. Trace Elements and Electrolytes 19: 6369.

Ademuyiwa O, Agarwal R, Chandra R \& Behari JR (2009). Lead-induced phospholipidosis and cholesterogenesis in rat tissues. ChemicoBiological interactions 179: 314-320.

Aly AA \& El-Beltagi HES (2010). Influencing of ionizing irradiation on the antioxidant enzymes of Vicia faba L, Grasa Y AceiteNew phytology 61 (3): 288-294.

Avadheshkumar R, Chauhan RS \& Singh NP (1998). Immunological effect of lead on cell mediated 
immunity in chicken. Industrial Journal of Veterinary Pathology 22 (1): 22-28.

Aydemir T, Ozturk R, Bozkaya LA \& Tarhan L (2000). Effect of antioxidant vitamins A, C, E and trace elements $\mathrm{Cu}$, Se on CuZnSOD, GSHPx, CAT and LPO levels in chicken erythrocytes. Cell Biochemistry and Functionality 18: 109115.

Buege JA \& Aust SD (1978). Microsomal lipid peroxidation. Methods in enzymology 52: 302- 05

Comporti M. (1993). Lipid peroxidation, biopathological significance. Molecular Aspect of Medicine 14: 199-207.

Correia PRM, Oliveira E \& Oliveira PV (2000). Simultaneous determination of $\mathrm{Cd}$ and $\mathrm{Pb}$ in foodstuffs by electro-thermal atomic absorption spectrometry. Annal Chim Acta 405(1-2): 205211.

El-Beltagi HS, Ahmed OK \& El-Desouky W (2011). Effect of low doses $\gamma$-irradiation on oxidative stress and secondary metabolites production of Rosemary (Rosmarinus officinalis L.) callus culture. Radiation Physiology and Chemistry 80 (9): 965-973.

El-Beltagi HS \& Mohammed AA (2010). Changes in non protein thiols, some antioxidant enzymes activity and ultrastructural alteration in radish plant (Raphanus sativus L) grown under lead toxicity. Not Bot Horticulture Agrobot Cluj $\mathbf{3 8}$ (3): 76-85.

Finkel AJ, Hamilton A \& Hardy HL (1983). Metal and metalloids. In: Finkel AJ, (ed), Industrial toxicity, $4^{\text {th }}$ ed. Boston, London: John Wright PSG Pp 62-67.

Foyer CH \& Noctor G (2002). Oxygen processing in photosynthesis: regulation and signaling. New Phytology 146: 359-388.

Frankel S \& Reitman S (1963). Clinical laboratory methods, In: St. Louis CV Mosby Coy. Pp 102105.

Gokhan E, Yucel C, Meryem E \& Bilal CL (2004). Changes in malondialdehyde level and catalase activity and effect of toltrazuril on these parameters in chicks infected with Eimeria tenella. Bulletin of Veterinary Institute 48: 251254.

Goyer RA (1991). Toxic effects of metals In: MO Amdur, J Doull \& CD Klassen (eds). Cassaret and Doull's Toxicology. The Basic Science of Poisons $\left(4^{\text {th }}\right.$ ed) Pergamon Press, New York. Pp 623-680.

Gurer H, Ozgunes H, Neal R, Spiz DR \& Ercal N (1999). Antioxidant role of alpha-lipoic acid in lead toxicity. Free Radical Biology Medicine 27: 75-81.

Gutterridge JMC \& Haliwell B (1993). The measurement and mechanism of lipid peroxidation in biological systems. Letters 3: 129-135.
Hashem MA \& El-Sharkawy NI (2009). Haematobiochemical and immunotoxicological effects of low electromagnetic field and its interaction with lead in mice. Iraqi Journal of Veerinaryt Science 23: 105-114.

Kihc E, Yazar S, Saraymen R \& Yalcm S (2003). Changes in the level of serum malondialdehyde in patients infected with Girdia intestinalis. Acta Parasitologica Turcica 27:184-186.

Makino S, Tsuruta H \& Takata T (2000). Relationship between blood lead level and urinary ALA level in workers exposed to very low levels of lead. Industrial Health 38: 95-98.

Maleeka A,Jarmuszkiewicz W \& Tomaszewska B (2001). Antioxidative defense to lead stress in subcellular compartments of pea root cells. Acta Biochim Pol 48: 687-698.

Moussa SA \& Bashandy SA (2008). Biophysical and biochemical changes in the blood of rats exposed to lead toxicity. Romanian Journal of Biophysis 18(2): 123-133.

Needleman HL, Scheel A, Bellinger D, Leviton A \& Allred E (1990). The long-term effects of exposure to lead in childhood. An 11- yr followup report. New England Journal of Medicine 322: 83-88.

Okediran BS, Ajibola ES, Olaniyi MO Oladele GM, Thomas FC, Rahman SA \& Adekunle MA (2010). Haematological and Biochemical Changes following Lead Toxicity in Male Wistar Rats. Folia Veterinaria 54(3):126-129.

Osterode W, Barnas U \& Geissle K (1999). Dose dependent reduction of erythroid progenitor cells and inappropriate erythropoietin response in exposure to lead: new aspects of anaemia induced by lead. Occupational Environmental Medicine 56: 106-109.

Osterode W \& Ulberth F(2000). Increased concentration of arachidonic acid in erythrocyte membranes in chronically lead-exposed men. Journal of Toxicoloy and Environmental Health, Part A 59: 87-95.

Ozturk-Urek R, Bozkaya LA \& Tarhan L (2001). The effect of some antioxidant vitamin and trace element-supplemented diets on activities of SOD, CAT,GSH-Px and LPO levels in chicken tissues. Cell Biochemistry and Functionality, 19: 125-132.

Panazzo PM, Basso D, Balint L, Biasin MR, Bonvicini P \& Metus P(1995). Altered lipid peroxidation/glutathione ratio in experimental extrahepatic cholestasis. Clinical Experimental Pharmacology and Physiology, 22: 266-71.

Sakai T (2000). Biomakers of lead exposure. Industrial Health 38: 127-142.

Schalm DW, Jain NC \& Carrot EJ (1975). Veterinary haematology $3^{\text {rd }}$ edn Lea and Febiger, Philadelphia.Pp 20-27.

Seddik L, Bah TM, Aoues A, Brnderdour M \& Silmani M (2010). Dried leaf extract protects against lead-induced neurotoxicity in Wistar rats. 
European Journal of Science Research 42(1): 1391-1400.

Shafiq-ur-Rehman S (1984). Lead-induced regional lipid peroxidation in brain. Toxicoloy Letter 21: 333-337.

Sharon LM (1966). Enzymatic assay of peroxidase. Journal of Biological Chemistry 241: 2166-2172

Sinha A (1972). Colorimetric assay of catalase. Anals of Biochemistry 47:389-95.

Sivaprasad R, Nagaraj M, \& Varalakshmi P (2004). Combined efficacies of lipoic acid and 2,3dimercaptosuccinic acid against lead-induced lipid peroxidation in rat liver. Journal of Nutritional Biochemistry 15: 18-23.

Somashekaraiah B, Padmaja K \& Prasad ARK (1992). Lead-induced lipid peroxidation and antioxidant defense components of developments of developing chick embryos. Free Radical Biology Medicine, 13: 107-114.

Spivey MR (1978). Nutritional considerations in designing animal models of metal toxicity in man. Environmental Health Perspective 25: 13740.

Suleiman FA, Mary A, Muftau S \& Mohammed UK (2011). Hematological changes induced by subchronic co-administration of chlorpyrifos and lead in Wistar rats: Alleviating effect of vitamin C. Der Pharmacia Sinica 2 (2): 276-284.

Wise RR \& Neylor AW (1987). Chilling-enhanced peroxidation: the peroxidative destruction of lipids during chilling injury to photosynthesis and ultrastructure. Plant Physiology 83: 227-272.

Xienna U, Foote GC, Van S, Devreotes PN, Alexander S \& Alexander, H (2000). Differential development expression and cell type specificity of Dicrocelium catalases and their response to oxidative and UV light. Biochim Biophys Acta 1492: 295-310.

Zhang FQ, Wang YS, Lou ZP, Dong JD (2007). Effect of heavy metals stress on oxidative enzymes and lipid peroxidation in leaves of two mangrove plant seedling (Kandelia candel and Bruguiera gymnorrhiza) Chemosphere 67: 44-50.

Zou GL, Gui XF, Zhong XL \& Zhu YF (1986). Improvements in pyrogallol autooxidation method for the determination of superoxide dismutase activity.Progress in Biochem Biophysis 71: 73-75. 